\title{
DIGITALIZACIJA POSLOVANJA SEKTORA SOCIJALNE I DJEČJE SKRBI U CRNOJ GORI - SOCIJALNI KARTON (IISSS)
}

Primljeno: prosinac, 2020.

Prihvaćeno: veljača, 2021.

UDK: 613.8:794.9

DOI 10.3935/ljsr.v28i1.413

Ida Kolinović ${ }^{1}$

https://orcid.org/0000-0001$5256-2687$

Ministarstvo rada i socijalnog staranja Crne Gore

SAŽETAK

Integrirani informacijski sustav socijalne skrbi (IISSS) Socijalni karton predstavlja digitalnu transformaciju u službi reforme sustava socijalne i dječje skrbi Crne Gore s ciljem da se siromašnima i socijalno ugroženima osigura što kvalitetnija socijalna skrb u dijelu materijalnih davanja i usluga socijalne $i$ dječje skrbi. Ovaj kapitalni projekt Vlade Crne Gore je značajno unaprijedio način rada centara za socijalni rad jer je podržao sve poslovne procese i omogućio stvaranje jedinstvenog »socijalnog kartona " građana uključenih u sustav socijalne i dječje skrbi. $U$ radu je predstavljen informacijski sustav u centrima za socijalni rad i javnim ustanovama za smještaj korisnika (koji uključuje direktnu praksu, donošenje odluka i upravljanje predmetima, protok i upravljanje informacijama, čuvanje povijesnih i ažuriranih podataka o korisnicima prava i njihovim obiteljima), kao i koristi sustava za korisnike, zaposlenike u socijalnoj $i$ dječjoj skrbi i kreatore politika. IISSS je unaprijedio kapacitete Vlade Crne Gore da planira, prati i upravlja socijalnom i dječjom skrbi. Razvoj i uvođenje ovog softvera zahtijevalo je intenzivnu suradnju i veliku posvećenost stručnjaka, zaposlenika u području socijalne i dječje skrbi, UNDP, softverske tvrtke S\&T (Srbija i Crna Gora) i Direktorata za informatiku i analitičko-statističke poslove Ministarstva rada i socijalnog staranja.

1 Ida Kolinović, Doktorandica na sveučilištu u Crnoj Gori, socijalna radnica, e-mail: ida.kolinovic@gmail.com

Direktorat za informatiku i analitičko-statističke poslove

Ključne riječi:

digitalizacija u socijalnoj skrbi, IISSS, materijalna davanja, usluge socijalne i dječje skrbi, ustanove za smještaj korisnika 


\section{UVOD}

Digitalna revolucija nametnula je potrebu za modernizacijom sustava socijalne i dječje skrbi i otvorila nove mogućnosti u suočavanju sa socijalnim problemima. Neki autori predlažu termin »informatika socijalnog rada za upotrebu tehnologija u praksi socijalnog rada koji predstavlja kombinaciju računarske i informatičke znanosti i socijalnog rada dizajniranih da pomognu u boljem upravljanju predmetima, obradi podataka, unapređenju i primjeni stručnih znanja i kvalitetnijem pružanju pomoći i podrške korisnicima socijalne i dječje skrbi (Lagsten i Andersson, 2018.).

Socijalni karton predstavlja digitalizaciju poslovanja sektora socijalne i dječje skrbi koji je trenutno implementiran na 34 fizičke lokacije u Crnoj Gori. Riječ je o kapitalnom projektu crnogorske Vlade koji je omogućio provedbu reforme sustava socijalne i dječje skrbi s ciljem da se siromašnima i socijalno ugroženima osigura što kvalitetnija socijalna skrb, kako u dijelu materijalnih davanja, tako i u dijelu usluga socijalne i dječje skrbi. Razvoj i uvođenje ovog softvera zahtijevalo je intenzivnu suradnju stručnjaka, zaposlenika u području socijalne i dječje skrbi, softverske tvrtke S\&T (Srbija i Crna Gora), kao i veliku posvećenost UNDP-a (koji rukovodi projektom) i Direktorata za informatiku i analitičko-statističke poslove Ministarstva rada i socijalnog staranja. Projekt se odvijao u fazama - prvo su implementirana materijalna davanja, potom usluge socijalne i dječje skrbi - faza I, i na kraju, u okviru faze II, javne ustanove za smještaj korisnika.

\section{DIGITALNA TRANSFORMACIJA CENTARA ZA SOCIJALNI RAD}

Od 1. siječnja 2015. godine informacijski sustav socijalne skrbi (IISSS) je u operativnom radu u svim centrima za socijalni rad, njihovim područnim jedinicama i Ministarstvu rada i socijalnog staranja. Sustav se dalje širio i unapređivao, pa danas uključuje sve poslovne procese u centrima za socijalni rad: prijem, priznavanje prava, upravljanje slučajevima i postupcima, obračun i isplatu materijalnih davanja/socijalnih transfera ${ }^{2}$ (na temelju potpisanih i trenutno aktivnih rješenja o ostvarivanju prava), praćenje i automatsku periodičnu provjeru dokaza uz pokretanje postupka revizije. IISSS obuhvaća sva materijalna davanja shodno Zakonu o socijalnoj i dječjoj zaštiti, davanja iz područja skrbi za sudionike rata i osobe s invaliditetom, vođenje slučaja s

2 Posredstvom IISSS se vrši isplata za sva materijalna davanja, uključujući i boračko-inavlidsku skrb, kao i za postupke udomiteljstva za djecu i odrasla lica. U pripremi je puštanje obračuna posredstvom IISSS i za postupke smještaja korisnika u Javne ustanove. 
postupcima, E-registre: registar korisnika prava, registar skrbnika, registar pružatelja usluga udomiteljstva, registar licenciranih pružatelja usluga (dnevni boravci, skloništa, SOS telefoni, ustanove, itd.) i registar licenciranih stručnih radnika u socijalnoj skrbi (za koji je nadležan Zavod za socijalnu i dječju skrb) i dva portala - portal za materijalna davanja i portal za poslodavce za podnošenje i procesuiranje zahtjeva za refundacije naknade plaće i naknada plaće za porodiljni, odnosno rodiljni dopust. Sastavni dio IISSS je i analitička, sofisticirana baza podataka kroz modul za poslovnu analitiku - Bysiness Intelligence (BI), koja je omogućila kvalitetno izvještavanje za materijalna davanja, usluge socijalne i dječje skrbi i javne ustanove za smještaj korisnika. Ovaj alat je također olakšao menadžerima u procesu organiziranja i bolje raspodjele radne snage, nadgledanja i praćenja procesa rada zaposlenika u centrima za socijalni rad i javnim ustanovama za smještaj korisnika, kao i identificiranje eventualnih grešaka i zloupotreba u radu te poduzimanja preventivnih mjera kako se navedeno ne bi ponavljalo. Informacijski sustav generira podatke u realnom vremenu čime su stvoreni preduvjeti za bolje analize svih dokaza i slučajeva. Zahvaljujući modulu interoperabilnosti (automatskoj razmjeni podataka s informacijskim sustavima drugih institucija) centri za socijalni rad postali su »one-stop shop« (jedinstveni šalter) u kojem su dostupni svi dokumenti za utvrđivanje podobnosti za materijalna davanja, a sustav generira i takozvane e-socijalne kartone (imovina, socijalni i radni status), odnosno socijalne profile pojedinaca/obitelji. Sustav je interoperabilan s 9 nacionalnih institucija (18 web servisa): Fond za penzijsko i invalidsko osiguranje, Fond za zdravstveno osiguranje, Zavod za zapošljavanje, Uprava za nekretnine, Poreska uprava, Ministarstvo unutrašnjih poslova (centralni registar stanovništva i registar motornih vozila), Ministarstvo prosvjete, Ministarstvo poljoprivrede i Veterinarska uprava. U IISSS su integrirani teritorijalni registar preuzet od Monstata i registar adresa preuzet od pošte Crne Gore ${ }^{3}$. IISSS pruža uvid o eventualnim višestrukim socijalnim davanjima, odnosno koliko pojedinac ili obitelj ukupno primaju po više osnova, te se pregledom svih davanja stvara bolja slika usmjeravanja sredstava. Sustav osigurava bolji uvid u to tko su korisnici i u kojem vremenskom periodu, filtrira one koji ne ispunjavaju uvjete, onemogućava dupliranja u procesima i nadoknadama i štedi na administrativnim troškovima.

Na početku Projekta provedena je Studija kapaciteta centara za socijalni rad u kojoj su analizirani i kadrovski kapaciteti, te konstatirana limitirana znanja iz područja računalne pismenosti. Projekt je podržao izradu novog Zakona o socijalnoj i dječjoj zaštiti, najznačajnijih podzakonskih akata, reorganizaciju centara za socijalni rad, uvo-

3 Sastavni dio sustava su i šifarnik centara za socijalni rad i područnih jedinica, šifarnik materijalnih davanja i usluga socijalne i dječje skrbi, šifarnik naselja i ulica, i više od 500 vrsta tipskih rješenja za priznavanje, odbijanje i prekid prava, čime je značajno olakšan posao pravnicima. 
đenje standarda, nove opise poslova i sistematizacije, kao i reinženjering procedura/ poslovnih procesa. Organizirani su mnogobrojni konzultativni sastanci radnih timova s predstavnicima Ministarstva, centara za socijalni rad i tvrtke S\&T zadužene za kreiranje i održavanje aplikacijskog softvera, na kojima su analizirani i definirani postupci, pravni okvir i testirane određene funkcionalnosti IISSS prije njihovog puštanja u operativni rad. Osigurana je neophodna tehnička oprema centrima za socijalni rad, provedene obuke informatičke pismenosti, obuke za rad u IISSS-u, stručne obuke, pripremljena uputstva za svaki postupak i osigurano kontinuirano praćenje i podrška zaposlenicima u socijalnoj i dječjoj skrbi u radu u informacijskom sustavu.

\section{Prijem i raspodjela zadataka u informacijskom sustavu}

Svi ljudi koji se obrate centrima za socijalni rad za informaciju, pomoć i podršku, evidentiraju se u okviru prijemnog lista u informacijskom sustavu, bez obzira na to ispunjavaju li uvjete za ostvarivanje nekog prava ili ne, odnosno je li problem iz domena nadležnosti centara za socijalni rad. Pored toga, prijemni list ima dodatne funkcionalnosti: promjena osobnih podataka, formiranje obitelji, promjena članova obitelji, izdavanje/ ispis uvjerenja i potvrda. Za svakog korisnika socijalne i dječje skrbi formira se obitelj (s jedinstvenim registarskim brojem), a jedan korisnik može pripadati samo jednoj obitelji. ${ }^{4}$ Ažurnost sastava obitelji je imperativ jer to utječe na ostvarivanje određenih prava na materijalna davanja. Tako se, na primjer, prilikom utvrđivanja imovine i prihoda, dokazi prikupljaju za sve članove obitelji, čime su spriječene zloupotrebe (npr. prilikom ostvarivanja prava na materijalno osiguranje). Dalje je važno naglasiti da za korisnike/ osobe koji nemaju jedinstveni matični broj JMB (npr. iseljenici), u sustavu postoji opcija generiranja matičnog broja kroz IISSS.

U slučajevima kada je problem korisnika iz područja socijalne i dječje skrbi, s prijema se pokreće postupak koji se potom pojavljuje u pregledu kod dispečera, najčešće rukovodioca u centru za socijalni rad/područnoj jedinici koji, između ostalog, ima zadatak određivanja voditelja predmeta, stručnog radnika, supervizora (kod predmeta vođenja slučaja), dodjele zadataka, preraspodjele zadataka i storniranja predmeta. Dispečeri, koji u svakom trenutku mogu vidjeti što je i u koje vrijeme koji zaposlenik napravio na predmetu, odnosno slučaju, mogu pratiti dinamiku rada na svim aktivnim predmetima, što osigurava bolji nadzor, monitoring kvaliteta rada zaposlenika i učinkovitiju procjenu, planiranje i upravljanje radnim procesima.

4 Prilikom smještaja npr. djeteta na udomiteljstvo, donošenjem (potpisivanjem) rješenja o smještaju, dijete automatski prelazi u udomiteljsku obitelj u IISSS-u. 


\section{Materijalna davanja u informacijskom sustavu socijalne skrbi}

U informacijskom sustavu nalaze se sva materijalna davanja propisana Zakonom o socijalnoj i dječjoj zaštiti Crne Gore (Zakon o socijalnoj i dječjoj zaštiti Crne Gore 2013., 2015., 2016., 2017.) osnovna materijalna davanja u socijalnoj skrbi: materijalno osiguranje, osobna invalidnina, dodatak za njegu i pomoć, zdravstvena zaštita, jednokratna novčana pomoć, troškovi sahrane, naknada roditelju ili staratelju korisnika prava na osobnu invalidninu

- osnovna materijalna davanja iz dječje skrbi: naknada za novorođeno dijete, dodatak za djecu, troškovi prehrane u predškolskim ustanovama, pomoć u odgoju i obrazovanju djece i mladih s posebnim obrazovnim potrebama (troškovi smještaja u ustanovu i troškovi prijevoza), refundacija naknade zarade za porodiljsko, odnosno roditeljsko odsustvo, naknada po osnovi rođenja djeteta, naknada za novorođeno dijete, naknada po osnovi rođenja troje ili više djece (i uplata doprinosa), naknada zarade za rad s polovinom radnog vremena.

Putem sustava realizira se i Postupak za ostvarivanje prava na povlastice na putovanje osoba s invaliditetom shodno Zakonu o povlastici na putovanje osoba s invaliditetom. U IISSS-u je implementirano i 11 davanja iz područja osoba s invaliditetom i osoba koje su sudjelovale u ratu (osobna invalidnina, dodatak za njegu i pomoć od strane druge osobe, ortopedski dodatak, obiteljska invalidnina i uvećana obiteljska invalidnina, novčana naknada materijalnog osiguranja, obiteljski dodatak, zdravstvena zaštita i druga prava u vezi sa ostvarivanjem zdravstvene zaštite, ortopedska i druga pomagala, fizioterapija i liječenje u toplicama, besplatna i povlaštena vožnja, pogrebni troškovi). Korisnici ovog prava su branitelj, vojni invalidi, obitelji palog borca, civilni invalid rata, članovi obitelji umrlog borca, vojnog invalida i civilnog invalida rata shodno Zakonu o boračkoj i invalidskoj zaštiti Crne Gore. Za razliku od materijalnih davanja - stavke 1 i 2 , gdje se kompletan proces odvija u centrima za socijalni rad u IISSS-u, u slučaju ostvarivanja prava na boračko-invalidsku skrb, za kompletan proces u informacijskom sustavu je zadužena osoba zaposlena u Ministarstvu rada i socijalnog staranja.

Sustav obrađuje kompletan postupak, od podnošenja zahtjeva do utvrđivanja i priznavanja prava, odnosno izdavanja pojedinačnih rješenja, obračuna, isplate (oko 8 milijuna eura mjesečno), revizija i praćenja. Putem IISSS-a vrši se i polugodišnje usklađivanje visine osnova za ostvarivanje prava na materijalna davanja, shodno Zakonu o socijalnoj i dječjoj zaštiti Crne Gore (2013., 2015., 2016., 2017.) Česte izmjene zakonskih propisa u dijelu materijalnih davanja nametnule su potrebu razvoja funkcionalnosti 
koja omogućuje paketnu obradu rješenja - zamjenu odabranih rješenja novim, automatskim prijenosom potrebnih podataka iz starih rješenja u nova, za koja je unaprijed napravljen obrazac. Tako je IISSS »oponašao« ručni postupak donošenja rješenja i obračuna (odnosno obustave isplata) i izdao preko 60000 pojedinačnih rješenja za nadoknade majkama s troje i više djece, zdravstvenu skrb, osobnu invalidninu itd. Bez ove funkcionalnosti ne bi bila moguća pravovremena provedba zakonskih izmjena.

Korisnici i podnositelji zahtjeva za materijalna davanja više se ne izlažu teškoćama i troškovima (prijevoz, administrativne pristojbe, vrijeme) vezanim za prikupljanje dokumentacije neophodne da bi ostvarili pravo. Ne moraju više "šetati od šaltera do šaltera« (npr. oko 30 dokumenata je potrebno za ostvarivanje prava na materijalno osiguranje), jer IISSS umjesto njih automatski pribavlja potrebne dokaze zahvaljujući modulu interoperabilnosti, odnosno automatskoj razmjeni podataka s drugim informacijskim sustavima. Korisnici su prije uvođenja sustava također bili obvezni dostaviti nove dokumente za potrebe revizije, shodno roku koji je propisan u zakonskim i podzakonskim aktima. Sada to više nije potrebno jer se dokumentacija automatski ažurira, pa su predmeti ažurirani, što ranije nije bio slučaj. Na ovaj način je IISSS značajno doprinio smanjenju "greške uključenosti«, odnosno eliminirao velik broj osoba (obitelji) koje nemaju pravo na materijalna davanja, a ostvarivali su ih prije uvođenja informacijskog sustava, što je omogućilo uštedu budžetskih sredstava i bolju usmjerenost materijalnih davanja. IISSS također predstavlja koristan alat za utvrđivanje "greške isključenosti«, kroz analize odbijenih zahtjeva i razloga neodobravanja prava na materijalno osiguranje (socijalnu pomoć) zbog rigoroznih zakonskih uvjeta i simulacije podnošenja zahtjeva za ostvarivanje prava, u cilju identifikacije siromašnih domaćinstava koje imaju pravo na socijalnu pomoć, a ne ostvaruju je. Spomenuto je od značaja za predlaganje zakonskih izmjena, u cilju boljeg targetiranja, odnosno većeg obuhvata siromašnog stanovništva socijalnom pomoći.

IISSS je dalje u velikoj mjeri olakšao stručnim radnicima u centrima za socijalni rad, rasteretio ih viška administrativnih poslova, što im je dalo više prostora za rad s korisnicima. Sustav osigurava transparentnost i veću individualnu odgovornost u radu zaposlenika jer se prilikom kreiranja i završetka svakog zadatka automatski bilježe vrijeme, datum zadatka i zaduženi stručni radnik. Zaposlenici u centrima za socijalni rad međusobno komuniciraju na predmetima putem informacijskog sustava (npr. stručni radnik po završetku rada na nalazu i mišljenju klikom šalje predmet pravniku da nastavi rad na predmetu u okviru svog zadatka; pravnik je u mogućnosti putem sustava vratiti predmet stručnom radniku ukoliko smatra da je potrebno doraditi Nalaz i mišljenje; jedni drugima uz zadatak mogu poslati komentare i obavijesti, itd.).

Velik broj kontrola i notifikacija (obavijesti/upozorenja) u IISSS-u umanjuju mogućnost pojave greške u radu stručnih radnika. U tom kontekstu, značajno je spomenuti revizije prava, a naročito one koje su rezultat unakrsne provjere dokaza 
putem interoperabilitija (npr. osoba je registrirana u centru za socijalni rad da je umrla) ili na osnovi informacija iz samog sustava (npr. doneseno negativno rješenje za materijalno osiguranje kao okidač za reviziju prava na dodatak za djecu i sl.). Sustav signalizira svaku promjenu u podacima umreženih baza od značaja za odlučivanje o daljnjoj uporabi prava.

U IISSS-u se nalazi i Postupak ostvarivanja prava na subvencije za električnu energiju (shodno Uputstvu o postupku i načinu provođenja programa subvencioniranja računa za električnu energiju i Uredbe o snabdijevanju ranjivih kupaca električne energije) na osnovi kojeg se u Ministarstvu rada i socijalnog staranja generiraju popisi korisnika koji su pravo ostvarili preko centra za socijalni rad (koji se potom objedinjuju s korisnicima boračko-invalidske skrbi i zavoda za zapošljavanje) i dostavljaju EPCG svakog mjeseca. Omogućen je također unos podataka u IISSS, iznosa subvencija za električnu energiju od Elektroprivrede Crne Gore i staračkih naknada od Ministarstva poljoprivrede. Kada je riječ o djeci bez roditeljske skrbi i djeci korisnicima materijalnog osiguranja, sustav je osigurao razmjenu informacija putem web servisa s Ministarstvom prosvete, od kojih se dobiva informacija o periodu boravka ove djece u predškolskoj ustanovi, na temelju kojih se generiraju fakture iz IISSS-a s iznosom troškova prehrane i boravka za svako dijete u određenoj predškolskoj ustanovi.

Postupak aktivacije radno sposobnih korisnika materijalnog osiguranja je također implementiran u IISSS shodno Zakonu o socijalnoj i dječjoj zaštiti i Pravilniku o sadržini i obliku individualnog plana aktivacije i načinu provođenja mjera socijalne uključenosti radno sposobnih korisnika materijalnog osiguranja. Kod ovog postupka osigurana je dvosmjerna komunikacija centara za socijalni rad i zavoda za zapošljavanje na pokretanju i praćenju postupka aktivacije. Omogućena je razmjena informacija koje se odnose na Plan aktivacije, uključujući i sve promjene u centru za socijalni rad i na zavodu za zapošljavanje od važnosti za plan (npr. u slučaju kada korisnik odbije razgovor za posao u ZZZ-u, u centru za socijalni rad u IISSS-u se automatski kreira prijedlog revizije s obrazloženjem; sve druge promjene koje se događaju na Planu aktivacije, ZZZ šalje centrima za socijalni rad. S druge strane, ukoliko se u centru za socijalni rad iz nekog razloga (npr. korisnik preminuo) donese negativno rješenje, sustav automatski šalje tu informaciju ZZZ nakon čega oni prekidaju plan i/li provode druge aktivnosti shodno njihovoj proceduri. Na osnovi ovog postupka, sustav filtrira sve radno sposobne korisnike materijalnog osiguranja.

Tijekom pandemije korona virusa, IISSS je, počev od ožujka 2020. godine, osigurao svakog mjeseca provedbu mjera - kontinuitet socijalnih prava. Zbog obustave rada socijalno-medicinskih povjerenstava osigurano je produženje ostvarivanja prava za korisnike materijalnog osiguranja po osnovi radne nesposobnosti, kao i za korisnike osobne invalidnine, dodatka za njegu i pomoć i subvencija za električnu energiju. Sustav je na ovaj način pokazao svoju sposobnost reagiranja u kriznim situacijama. 


\section{Usluge socijalne i dječje skrbi u informacijskom sustavu socijalne skrbi}

Socijalni karton se najčešće pogrešno poistovjećuje samo s materijalnim davanjima i zapostavlja se vođenje slučaja, koje obuhvaća velik dio informacijskog sustava, a što je u biti i najvažniji aspekt socijalnog rada. Informacijski sustav socijalne skrbi obuhvaća usluge socijalne i dječje skrbi - modul Vođenja slučaja s postupcima, shodno Zakonu o socijalnoj i dječjoj zaštiti i relevantnim pravilnicima ${ }^{5}$. IISSS obuhvaća kompletan proces koji uključuje prijem, procjenu, plan, realizaciju plana, monitoring, evaluaciju i ponovni pregled, pokretanje postupaka u okviru vođenja slučaja, izradu nalaza i mišljenja i donošenje rješenja, zatvaranje slučaja. IISSS je omogućio brz i jednostavan pregled/pretragu slučajeva po različitim kriterijima, a karakteristika po kojoj je svaki korisnik jedinstven u informacijskom sustavu je svakako jedinstveni matični broj. U IISSS-u se nalazi više od 40 postupaka za usluge socijalne i dječje skrbi: procjena podobnosti pružatelja usluga udomiteljskog smještaja, udomiteljstvo za djecu i odrasle osobe, skrbništvo, smještaj u ustanove, nadzor nad izvršavanjem roditeljskog prava, zaštita od nasilja, savjetodavno-terapijske usluge, neodložne intervencije, pokretanje postupka pred sudom, sudjelovanje u sudskom postupku, suglasnost organa starateljstva za otuđenje imovine, itd., kao i tiskanje svih izvještaja/ obrazaca propisanih pravilnicima. Putem informacijskog sustava odvija se i kompletna komunikacija između voditelja slučaja, drugih stručnih radnika i supervizora u vezi konkretnih predmeta, čime se postiže efikasnost, pravodobnost i transparentnost u radu. Uvođenje modula vođenja slučaja u centre za socijalni rad bez informacijskog sustava teško bi bilo moguće realizirati u praksi.

Značajno je naglasiti da je sustav uvezan kao cjelina, odnosno da su u informacijskom sustavu socijalne skrbi materijalna davanja povezana s uslugama socijalne i dječje skrbi. Za svakog korisnika u IISSS-u postoji dosje te se na brz i jednostavan način preko jedinstvenog matičnog broja mogu pratiti svi postupci vezani za tog korisnika, bilo da se radi o uslugama socijalne i dječje skrbi ili materijalnim davanjima. Za svakog korisnika su također uneseni podaci o njegovoj obitelji po principu da svaki korisnik može pripadati samo jednoj obitelji, a formiranje obitelji je bitno kako bi se pratila ukupna obiteljska situacija, odnosno potrebe obitelji za uslugama socijalne i dječje skrbi (i materijalnim davanjima). Važno je spomenuti da korisnik može imati dosje, odnosno "pripadati« samo jednom centru za socijalni rad u IISSS-u - informacijski sustav mu »neće dozvoliti« da koristi prava u dva različita centra, čime su spriječene

5 Ministarstvo rada i socijalnog staranja donijelo je novi Pravilnik o organizaciji, normativima, standardima i načinu rada centara za socijalni rad 31.7.2019. godine, čime je značajno izmijenjen dijagram vođenja slučaja u IISSS-u i prilagođen radu voditelja slučaja, u cilju unapređenja njihove efikasnosti i kvalitetnijeg pružanja pomoći i podrške korisnicima (Službeni list Crne Gore, br. 058/13 od 20.12.2013., 030/15 od 12.6.2015., 017/16 od 11.3.2016.). 
zloupotrebe (IISSS kontrolira/provjerava sve centre za socijalni rad, sve korisnike i članove obitelji). Dosje se uslijed promjene nadležnosti, prosljeđuje putem IISSS-a iz jednog centra za socijalni rad u drugi.

Kod postupka smještaja korisnika u javne ustanove - domove starih, Zavod »Komanski most«, Centar »Ljubović«, Dječiji dom »Mladost», centri za socijalni rad zahtjeve za smještaj korisnika u spomenute ustanove šalju putem informacijskog sustava (s potrebnom dokumentacijom). Ustanove na ovaj zahtjev također odgovaraju centrima za socijalni rad putem informacijskog sustava ("zahtjev prihvaćen«, "potrebna dopuna dokumentacije», "zahtjev se odbija ili »lista čekanja«), a zahtjev može biti i otkazan od strane centra za socijalni rad. Spomenute javne ustanove i centri za socijalni rad međusobno komuniciraju putem informacijskog sustava i naprednih lista praćenja, u vezi konkretnog korisnika - šalju jedni drugima obavijesti, informacije, odobrenja organa skrbništva za konkretnog štićenika, i slično. Prilikom premještanja korisnika s jednog odjela na drugi odjel u ustanovi (npr. s odjela gerijatrije na odjel za palijativnu skrb), voditelj slučaja zadužen za korisnika u centru za socijalni rad, automatski dobiva obavijest kroz IISSS da je korisnik premješten, te da je potrebno pokrenuti reviziju rješenja i donijeti novo, jer je cijena smještaja na novom odjelu veća. U IISSS-u je implementiran i Postupak za upućivanje djece u JU za odmor i rekreaciju »Lovćen - Bečići«.
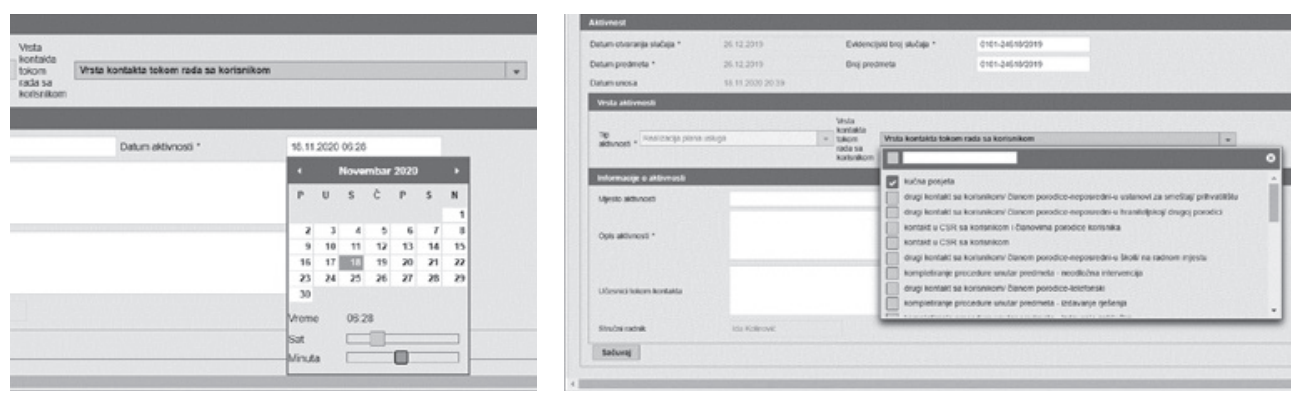

Slika 1. Izgled Lista praćenja - vođenje slučaja ${ }^{6}$

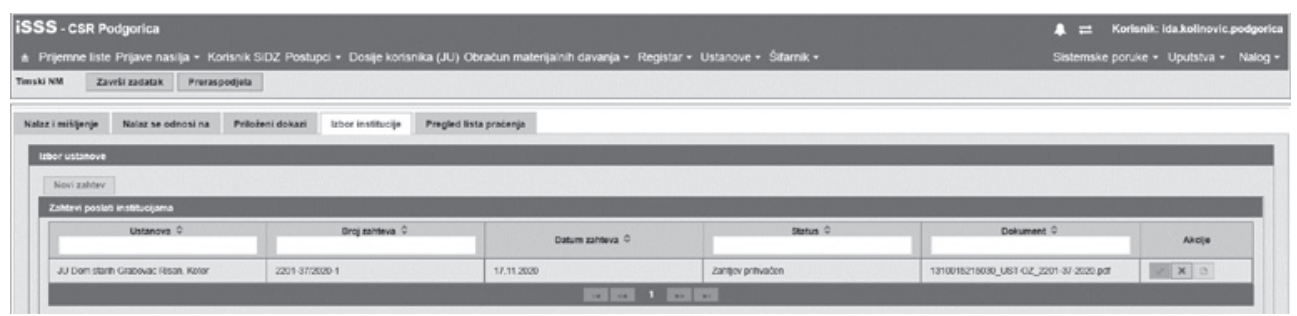

Slika 2. Timski nalaz i mišljenje - status »zahtjev prihvaćen« od ustanove, vidljiv u centru za socijalni rad

6 Sve slike iz Informacijskog sustava socijalnog staranja napravljene su u testnom okruženju, podaci su fiktivni. Slike su prikazane uz odobrenje menadžerice projekta Socijalni karton, Aleksandre Višnjić iz UNDP Crne Gore. 
Informacijski sustav socijalne skrbi sadrži registar pružatelja usluga obiteljskog udomiteljstva za djecu i odrasla lica. Po završetku Postupka procjene podobnosti pružatelja usluga, ukoliko je osoba procijenjena kao podobna, automatski se pojavljuje u registru. $U$ registru su dostupne informacije o tipu udomiteljske obitelji, povijesti udomiteljstva, broju osoba na smještaju, broju slobodnih mjesta, centru za socijalni rad koji je procijenio pružatelja usluge, izvještaj o procjeni podobnosti osoba za pružanje usluga udomiteljstva za djecu i odrasle osobe. Donošenjem pozitivnog rješenja o udomiteljstvu, popunjavaju se slobodna mjesta u registru, a isto tako se, donošenjem negativnog rješenja, upražnjavaju mjesta u registru kod određenog pružatelja usluga. Ukoliko pružatelj usluga više ne ispunjava uvjete za pružanje usluge ili ne želi više biti udomitelj, provodi se revizija procjene podobnosti u IISSS-u i pružatelj se uklanja iz registra. Registar pružatelja usluga osigurao je da svi centri za socijalni rad na jednostavan i brz način mogu pristupiti bazi slobodnih i dostupnih pružatelja usluge udomiteljstva na cijelom teritoriju Crne Gore. Sastavni dio IISSS-a je i registar skrbnika s podacima o skrbniku i licima pod skrbništvom.

U informacijski sustav socijalne skrbi implementirana je i Jedinstvena elektronska baza za nasilje u obitelji, koja povezuje Ministarstvo rada i socijalnog staranja (centre za socijalni rad) i Ministarstvo unutrašnjih poslova (uprave policije). Prijave obiteljskog nasilja od centra za socijalni rad i obavijesti od uprave policije, razmjenjuju se na unificiran i automatiziran način, a te obavijesti sadrže sve neophodne podatke o svim sudionicima u slučaju prijavljenog nasilja, shodno Protokolu o postupanju, prevenciji i zaštiti od nasilja nad ženama i nasilja u porodici: (potencijalnim) počiniteljima, (potencijalnim) žrtvama, svjedocima nasilja, djeci (ukoliko su djeca direktne žrtve ili žive u obitelji u kojoj se dogodilo nasilje, odnosno svjedoci, tj. indirektne žrtve), procesuiranim prekršajnim i krivičnim prijavama, događajima nasilja, procijenjenom stupnju rizika, izrečenim naredbama udaljenja iz stana, itd. Bez obzira na to je li prijava sumnje na obiteljsko nasilje stigla u upravu policije od centra za socijalni rad ili neke druge institucije, organizacije, građana ili građanki, sve obavijesti od uprave policije slivaju se u informacijski sustav socijalne skrbi- Socijalni karton, odnosno kod centara za socijalni rad. Pored toga što je ovaj postupak osigurao jedinstven i standardiziran način evidentiranja slučajeva obiteljskog nasilja i pravovremeno postupanje u oba odjela, osigurao je i kvalitetno izvještavanje o događajima obiteljskog nasilja: žrtvama, počiniteljima, svjedocima, srodstvu žrtava s počiniteljima nasilja, broju ponovljenog nasilja nad istim žrtvom, broju događaja nasilja u kojima su djeca dio obitelji, stupnju rizika, događajima u kojima je izrečena policijska naredba udaljenja iz stana, izrečenim zaštitnim mjerama, vrstama obiteljskog nasilja, itd. 


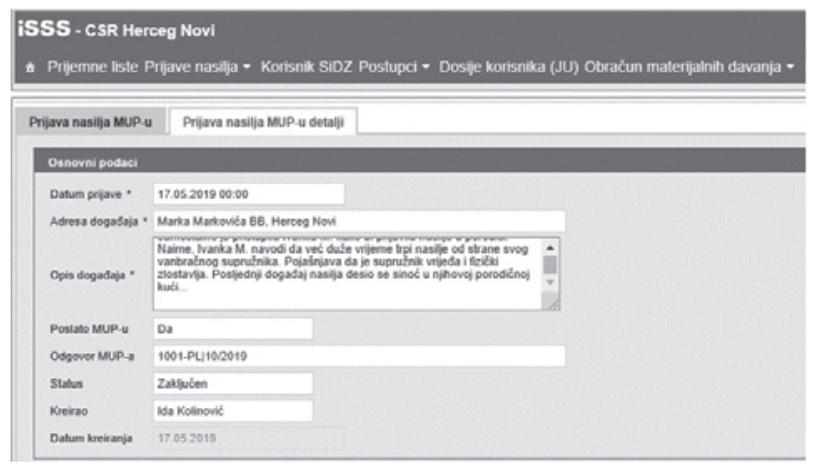

Slika 3. Izgled prijave nasilja u obitelji Upravi policije od strane Centra za socijalni rad

\section{JAVNE USTANOVE ZA SMJEŠTAJ KORISNIKA U INFORMACIJSKOM SUSTAVU SOCIJALNE SKRBI}

U okviru Faze II (koja je počela u 2016. godini) razvijeni su informacijski sustavi javnih ustanova socijalne i dječje skrbi za smještaj korisnika. Datumi početka implementacije socijalnog kartona u ovim ustanovama su: Dom starih »Grabovac» Risan - 30.5.2016. godine, Dom starih »Bijelo Polje» - 13.6.2016. godine, Dječiji dom »Mladost " - 19.9.2016. godine, Zavod »Komanski most» - 3.10.2016. godine i Centar »Ljubović« -17.10.2016. godine i Dom starih »Pljevlja« 5.12.2018. godine.

Ovome su prethodile mnogobrojne intenzivne aktivnosti: radionice, konzultacije s radnim timom, izrada prototipa, analiza i konzultacije vezane za pravilnike, obuke računalne/informatičke pismenosti i unos aktivnih predmeta smještaja u ustanove u centrima za socijalni rad, priprema predmeta za unos u ustanove, izrada/revizija svih individualnih planova za korisnike, obuke svih zaposlenika za rad u informacijskom sustavu (pripremljena su i uputstva) i inicijalni unos u javne ustanove, a potom i praćenje njihovog rada, korekcije u informacijskom sustavu na temelju identificiranih sugestija i svakodnevna pomoć u implementaciji.

Priprema za implementaciju socijalnog kartona u ustanovama socijalne i dječje skrbi je obuhvatila:

- tehničku pripremu aplikacije centara za socijalni rad i realiziranje obuke za voditelje slučaja i pravnike za rad u novoj aplikaciji

- tehničku pripremu aplikacije ustanova socijalne i dječje skrbi

- testiranje aplikacija od strane Ministarstva rada i socijalnog staranja prije stavljanja u funkciju

- pripremu dokumentacije iz dosjea korisnika za inicijalni unos od strane zaposlenika u ustanovama 
- inicijalni unos predmeta smještaja korisnika od strane centara za socijalni rad.

- Informacijskim sustavom obuhvaćen je cjelokupan proces smještaja korisnika:

- otvaranje slučaja u centrima za socijalni rad (vođenje slučaja)

- pokretanje postupka smještaja u okviru vođenja slučaja korisnika, te slanje zahtjeva za smještaj određenoj ustanovi

- obrada zahtjeva u ustanovi i donošenje odluke potpisom upravitelja

- ukoliko je odgovor ustanove na zahtjev pozitivan (što je vidljivo u aplikaciji centara), centar za socijalni rad donosi rješenje o smještaju korisnika

- zaposlenici u ustanovi rade prijem korisnika i zajedno sa zaposlenicima iz centra za socijalni rad izrađuju individualni plan korisnika u roku koji je predviđen relevantnim pravilnikom

- u Socijalnom kartonu zaposlenici u ustanovi bilježe svoj svakodnevni rad kompletne aktivnosti socijalne službe, medicinske službe, blagajne, ljekarne, portira, itd.

- komunikacija između ustanova i centara za socijalni rad se također odvija u informacijskom sustavu

- komunikacija između zaposlenika u ustanovi odvija se putem informacijskog sustava: dostavljaju obavijesti o realiziranim i nerealiziranim, a planiranim aktivnostima (socijalna i medicinska služba), obavijesti o posjetama i izlascima korisnika, itd.

- u IISSS-u se odvija i premještaj korisnika s jednog odjela na drugo, kao i promjena vrste ugovora o smještaju (sa smještaja preko centra za socijalni rad na smještaj putem direktnog ugovaranja s ustanovom i obrnuto)

- putem IISSS-a se odvija i otpust korisnika iz ustanove.

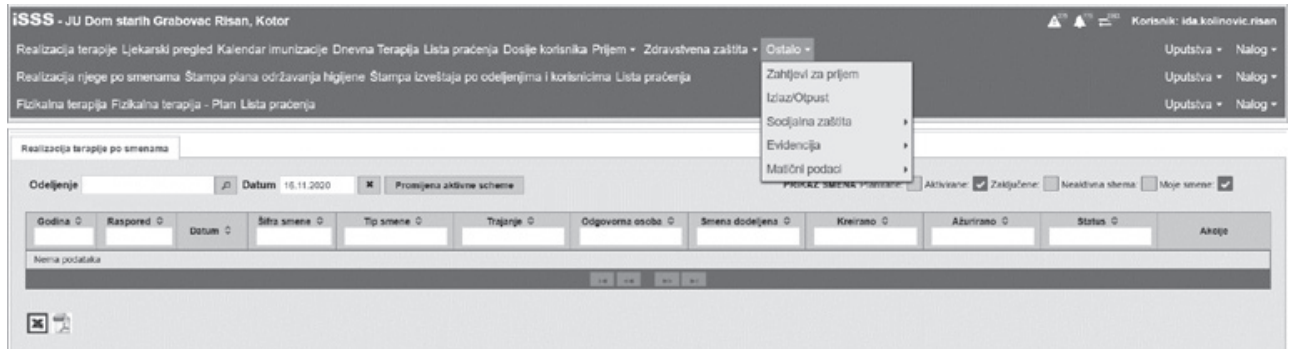

Slika 4. Izgled aplikacije (sa svim ulogama) u javnoj ustanovi za smještaj korisnika

U informacijskom sustavu nalaze se svi poslovni procesi u ustanovi, koji uključuju socijalnu, medicinsku i pravnu službu:

1) Upravljanje kapacitetima ustanove: pregled korisnika po odjelima i broju sobe; pregled odjela s brojem slobodnih, zauzetih i rezerviranih kreveta; odobravanje prijema novih korisnika na smještaj 
2) Socijalna skrb: obrada zahtjeva za smještaj (zahtjev iz CSR-a ili direktno ugovaranje s korisnikom), odgovor na zahtjev, prijem korisnika, individualni plan rada s korisnikom i realizacija aktivnosti kroz liste praćenja korisnika, ponovni pregled, radno-okupacijska terapija; potvrde o odobrenom odsustvu; knjiga dnevnih događaja; knjiga incidentnih događaja; grupni rad s korisnicima, komunikacija s centrima za socijalni rad putem napredne liste praćenja u vezi konkretnih korisnika na smještaju; obavijesti rukovoditeljima o poduzetim radnjama, premještaj korisnika s jednog odjela na drugi odjel, otpust korisnika

3) Zdravstvena skrb: prijem korisnika, izvještaj liječnika, liječnički pregled, dnevna terapija, tjedni plan terapije, realizacija terapije, realizacije terapije po smjenama, evidentiranje dijeljenja terapije svakom korisniku, realizacija njege po smjenama, planiranje mjesečnog rasporeda, izdavanje recepata i uputa (specijalisti, za laboratoriju, konzilijum liječnika, uputnica za MR, itd.), plan fizikalne terapije i provedba fizikalne terapije, tiskanje izvještaja po odjelima i korisnicima, ljekarna - prijem lijekova od dobavljača, ulaz/ izlaz lijekova.

4) Ostalo:

- blagajna (unos novčanih sredstava korisnika u blagajnu - tip blagajne, lista, dnevnik blagajne, izvještaj blagajne, tisak evidencije isplate novčanih sredstava), evidencija osobne imovine, pravna služba

- evidencija posjeta korisniku, evidencija dnevnih izlazaka korisnika iz ustanove kao i njihov povratak, tip posjete - redovna, kontrolirana, nedozvoljena, datum i vrijeme posjete, obavijesti nadležnih o tome, itd.

- dosje korisnika koji sadrži sve podatke i aktivnosti koje se odnose na određenog korisnika, na jednom mjestu.

\section{ULOGE I PRIVILEGIJE U INFORMACIJSKOM SUSTAVU}

Privilegije na određeni dio informacijskog sustava definirane su korisničkim ${ }^{7}$ nalozima i ulogama koje se dodjeljuju zaposlenicima u socijalnoj i dječjoj skrbi, od strane Ministarstva rada i socijalnog staranja. Uloge su podešene na takav način da dodavanje određene uloge podrazumijeva »davanje " privilegija na određeni dio informacijskog sustava, shodno zadacima i odgovornostima. Svaki korisnik informacijskog sustava (zaposlenici u socijalnoj i dječjoj skrbi) pristupa sustavu preko svog naloga sa šifre koju jedino on zna. Svaki zadatak koji odradi u sustavu sa svog naloga bilježi se u sustavu pod njegovim imenom i prezimenom.

\footnotetext{
7 Korisnici su s aspekta informacijskog sustava, zasposlenici u socijalnoj i dječjoj skrbi, koji rade u IISSS-u.
} 
Uloge u sustavu imaju i određene nazive i svaka podrazumijeva privilegije na konkretne dijelove informacijskog sustava. Tako, na primjer, u centrima za socijalni rad postoje uloge: dispečer - koja se uglavnom dodjeljuje rukovodiocima službi zaduženima za raspodjelu predmeta i praćenje dinamike rada zaposlenika na predmetima; obrada prijava nasilja - dodjeljuje se osobama odgovornim za prijem obavijesti od uprave policije i slanje prijava obiteljskog nasilja upravi policije kroz informacijski sustav; obuka udomitelja - stručnim radnicima koji su prošli trening provođenja obuke pružatelju usluge udomiteljstva, prijemni radnik - stručni radnik zadužen za poslove prijema i obradu zahtjeva za materijalna davanja; pravnik - odgovoran za kreiranje rješenja i validiranje dokaza, itd. Na isti se način upravlja privilegijama u javnim ustanovama socijalne i dječje skrbi, dodavanjem uloga: JU_individualni plan, JU_zdravstvena skrb, JU_glavna sestra, JU_psiholog, JU_blagajnik, JU_direktor, itd. Uloge su podešene tako da svaki stručni radnik ima pristup svojim predmetima i dijelovima aplikacije od značaja za njegov rad, čime se osigurava povjerljivost i zaštita podataka korisnika socijalne i dječje skrbi.

\section{RASPRAVA I ZAKLJUČNA RAZMATRANJA}

Digitalizacija socijalne i dječje skrbi kroz IISSS omogućila je provedbu reforme sustava socijalne i dječje skrbi, pravičnost, efikasnost, transparentnost, unificiranost rada centara za socijalni rad, poštovanje zakona i podzakonskih akata, smanjenje administrativnih troškova, papirologije i ručnog izvještavanja, bolju kvalitetu rada zaposlenika, učinkovitije upravljanje kapacitetima, poslovnim procesa i njihovim tokovima. Unaprijeđeni su procesi identifikacije, verifikacije, validacije, obrade, analize $\mathrm{i}$ isplate, bolji nadzor, te preveniranje i sprječavanje prevara i zloupotreba. Socijalni karton je osigurao bolji i brži pristup uslugama socijalne i dječje skrbi i materijalnim davanjima, poboljšao kvalitetu i praćenje pružanja usluga, osigurao adekvatnost socijalnih davanja, pravičnost i učinkovitost prilikom ostvarivanja prava - prava ostvaruju samo oni koji ispunjavaju uvjete i na načine propisane zakonima i podzakonskim aktima. Sustav je eliminirao velik broj osoba koje nemaju pravo na materijalna davanja, a ostvarivali su ih prije digitalizacije sustava socijalne i dječje skrbi, čime je ostvarena optimizacija budžetskih izdvajanja za socijalnu i dječju skrb, kroz bolje usmjeravanje materijalnih davanja (smanjenje »greške uključenosti«). IISSS predstavlja i značajan digitalni alat za analize i simulacije u cilju definiranja zakonskih izmjena, a radi smanjenja "greške isključenosti«.

Kada je rad zaposlenika u socijalnoj skrbi u pitanju, IISSS je značajno doprinio većoj individualnoj odgovornosti stručnih radnika, samom činjenicom što je osigurano da svaka poduzeta radnja u sustavu bude zabilježena. Digitalizacija procesa u 
socijalnoj i dječjoj skrbi u Crnoj Gori omogućila je brz i jednostavan pristup (na »klik«) dosjeima, povijesti predmeta, ishodima pružanja pomoći i podrške i isplatama, što sve doprinosi boljoj kvaliteti rada s korisnicima. Pristupi određenim dijelovima sustava regulirani su korisničkim nalozima, ulogama i privilegijama, pa je zaštita povjerljivosti podataka o korisniku na visokoj razini.

IISSS je također poboljšao kvalitetu i dostupnost podataka iz sustava socijalne i dječje skrbi koji su od značaja menadžmentu sustava socijalne skrbi i kreiranju socijalne politike, ali i za praćenje kvaliteta rada na predmetima.

Analiza rada centara za socijalni rad u Crnoj Gori u 2018. godini je otkrila da je tri četvrtine stručnih radnika (75\%) mišljenja da je informacijski sustav u potpunosti ili u velikoj mjeri prilagođen potrebama njihovog posla, dok oko jedne četvrtine (25\%) smatra da nije prilagođen u dovoljnoj mjeri (IDEAS, 2019.). Poslije spomenute analize napravljena je izmjena Pravilnika o organizaciji, normativima, standardima i načinu rada centara za socijalni rad 31.7.2019. godine, čime je značajno izmijenjen dijagram vođenja slučaja u IISSS-u i znatno bolje prilagođen radu zaposlenika u socijalnoj i dječjoj skrbi. Također su implementirane i dodatne optimizacije i unapređenja pojedinih funkcionalnosti IISSS-u (na osnovi kontinuiranog praćenja, evaluacije sustava i povratne informacije zaposlenika), pa se može pretpostaviti da bi sada stupanj zadovoljstva zaposlenika sustavom bio na većoj razini. Aktivno sudjelovanje zaposlenika u socijalnoj i dječjoj skrbi u kreiranju IISSS-a imalo je također pozitivan utjecaj na usvajanje i daljnju uporabu ovog naprednog sustava.

Za potrebe ovog rada provedeno je istraživanje među zaposlenicima u šest spomenutih javnih ustanova za smještaj korisnika socijalne i dječje skrbi u kojima je IISSS implementiran. Većina ispitanika u ovom istraživanju ocijenila je stupanj prilagodbe sustava njihovom radu u prosjeku s 3,9, a stupanj olakšanosti rada uvođenjem IISSS-a s 3,7 (na ljestvici od 1 do 5). Kao konkretne koristi od informacijskog sustava zaposlenici su naveli: sustavnost i preglednost, brz pristup podacima, lakše evidentiranje i praćenje rada, uštedu vremena i povećanu efikasnost u radu, brzu komunikaciju među institucijama i zaposlenicima, nemogućnost preskakanja koraka koji su propisani pravilnicima i zakonima, analitiku i izvještavanje, i slično, dok kao nedostatke vide povremeni pad sustava, pojavu sporog učitavanja podataka, složenost pojedinih aspekata IISSS-a za korištenje, probleme koji se javljaju u slučaju neažurnog rada u sustavu (prije svega u medicinskoj službi ustanova), i slično.

$\mathrm{U}$ informacijskom sustavu nalaze se obrasci koji su propisani zakonskim i podzakonskim aktima, zbog čega se ne može govoriti o utjecaju informacijskog sustava na obim dokumentacije. Pogrešna je pretpostavka pojedinaca da IISSS predstavlja prepreku dobroj praksi, da socijalni rad sada djeluje više na terenu »informatičkog" nego "socijalnog" te da socijalni radnici od računala »ne vide korisnika». Sustav im je značajno olakšao jer ih navodi na svaki naredni korak u radu, s poljima koje trebaju 
ispuniti (koje bi inače morali ispunjavati ručno na papiru), s mnogobrojnim kontrolama i notifikacijama koje im olakšavaju posao i smanjuju mogućnost pojave pogreške ili zloupotrebe. IISSS ni na koji način ne zamjenjuje stručni rad, terenske posjete i face to face kontakt sa korisnicima.

Pojava problema koji nekada mogu otežati rad u IISSS-u: "pad sustava«, pojava tehničkih problema, povremeno usporavanje sustava, pojava problema kod privlačenja podatka preko interoperabilitija, i slični problemi otklanjaju se u najkraćem roku od strane Ministarstva rada i socijalnog staranja i suradnika (softverska i hardverska podrška), koji također vode brigu o sustavu i prate njegovu funkcionalnost. Kada je riječ o statističkim podacima, od značaja za kvalitetno analitičko i statističko izvještavanje je da rad zaposlenika u IISSS-u bude ažuran s unosom točnih i preciznih podataka. Kod postupaka za koje se realizira obračun posredstvom sustava može se govoriti o sigurnoj pouzdanosti podataka koji se dobivaju iz informacijskog sustava, kao rezultat radnih procesa u IISSS-u (BI modul za poslovnu analizu). U svakom slučaju, podaci dobiveni putem IISSS-a mogu se smatrati mnogo kvalitetnijim od podataka koji se prikupljaju na temelju dokumentacije na papiru.

Za uspjeh ovog projekta od presudnog značaja je bio velik trud i entuzijazam zaposlenika u socijalnoj i dječjoj skrbi, zaposlenika u Direktoratu za informatiku i analitičko-statističke poslove Ministarstva rada i socijalnog staranja, sjajno upravljanje projektom i kontinuirana podrška od strane UNDP-a i odlično partnerstvo i suradnja sa softverskom tvrtkom S\&T (Srbija i Crna Gora). U cilju uspješnog provođenja reformi sustava socijalne skrbi i kako bi sve što je velikim radom i trudom uspješno napravljeno bilo i održivo, odnosno kako bi sustav zaživio u svom punom kapacitetu, osigurana je intenzivna podrška zaposlenicima, dorade i razvoj novih funkcionalnosti informacijskog sustava, kao i osiguranje višegodišnjih ugovora za održavanje softvera, hardvera, mreža i serverske infrastrukture. Trenutno su u fazi preostale (manje) dorade funkcionalnosti informacijskog sustava, kao i izmjene koje su nametnuli novi pravni propisi. Sustav i dalje ostavlja prostor za nadogradnju (npr. integraciju novootvorenih javnih ustanova socijalne i dječje skrbi u IISSS-u) i povezivanje IISSS-a $\mathrm{s}$ još nekim institucijama, u smislu interoperabilnosti i razmjene podataka (npr. $\mathrm{s}$ lokalnom samoupravom/ općinama ${ }^{8}$ ). U narednom periodu, moguće je također i uspostavljanje jedinstvene Baze za vršnjačko nasilje (koja podrazumijeva razmjenu podataka o prijavama nasilja s Ministarstvom prosvjete) i kreiranje Elektronske knjige usvojenja. Međutim, treba imati na umu da IISSS predstavlja izuzetno kompleksan »živi organizam« te da širenje, odnosno dodavanje novih sadržaja, može opteretiti ili usporiti sustav.

8 Da bi se spomenuto realiziralo, lokalna samouprava/ općine trebaju imati svoj informacijski sustav. 


\section{LITERATURA}

1. Lagsten, J. \& Andersson, A. (2018). Use of Information systems in social workchallenges and an agenda for future research. European Journal of Social Work, 21 (6), 1-13, https://doi.or/10.1080/13691457.2018.1423554

2. IDEAS (2019). Analiza rada centara za socijalni rad u Crnoj Gori. Podgorica: Ministarstvo rada i socijalnog staranja i UNICEF Crna Gora.

3. Zakon o socijalnoj i dječjoj zaštiti Crne Gore $(2013,2015,2016,2017)$. Službeni list Crne Gore, br. 1/2015., 42/2015., 47/2015., 56/2016., 66/2016., 1/2017., 31/2017., 42/2017., 50/2017. 
Ida Kolinović

\section{DIGITALIZATION OF SOCIAL AND CHILD PROTECTION BUSINESS SECTORS IN MONTENEGRO - SOCIAL CARD (SWIS)}

\section{ABSTRACT}

Social Welfare Information System (SWIS) - Social Card is digital transformation in the service of the social and child protection system reform in Montenegro, with the aim of providing the highest quality of social protection for the poor and socially endangered, in the area of material benefits and social and child protection services. This capital project of the Montenegrin Government has significantly improved the way social work centers' work, because it has supported all business processes and enabled the creation of a single "social card" of the citizens involved in the system of social welfare and child protection services. This paper presents the information system in social work centers and public institutions for accommodation of beneficiaries (which include direct practice, decision-making and case management, information flow management, storage of historical and up-to-date data on beneficiaries and their families), as well as the benefits of this system for beneficiaries, social and child welfare employees and policy makers. SWIS is an important instrument for targeted funding, provision, monitoring and control of material benefits and services provided to families and individuals, and it has improved the capacity of the Government of Montenegro to plan, monitor and manage social and child protection services. The development and introduction of this software required intensive cooperation of experts, employees in the field of social and child protection, software company S\&T (Serbia and Montenegro), UNDP and the Directorate for Informatics and Analytical and Statistical Affairs of the Ministry of Labor and Social Welfare.

Key words: digitalization in social protection; SWIS; material benefits; social and child protection services; institutions for accommodation of users

\section{(c) $(1)(9)$}

Međunarodna licenca / International License:

Creative Commons Attribution-NonCommercial-NoDerivatives 4.0. 